\title{
Differences Between Schools of Choice and Traditional Comprehensive Schools in Their Grade 9 Academic Performance
}

\author{
Divina Browne ${ }^{1}$, and John R. Slate ${ }^{2 *}$ \\ ${ }^{1,2}$ Sam Houston State University, United States of America \\ *e-mail: jrs051@shsu.edu
}

\begin{abstract}
This study was conducted to determine the differences between schools of choice and traditional comprehensive high schools in terms of their Grade 9 State of Texas Assessments of Academic Readiness (STAAR) End-of-Course (EOC) exams in Biology, English 1, and Algebra 1 during the 2017-2018 school year. Inferential statistical analyses revealed the presence of a statistically significant difference between the two types of schools on their EOC exam passing rates in all three content areas for students who were not at-risk and for students who were not in poverty. In contrast, statistically significant differences were not revealed between the two types of schools in terms of the EOC exam passing rates of their CATE and Non-CATE students. Knowing that students who have choice appear to perform better academically, policymakers are encouraged to study the feasibility of channeling more funding to help school districts expand their school choice programs to (a) motivate more students to find the school that fit their needs and their future college and career aspirations, and (b) to solicit more support from parents and community businesses to invest in their communities to improve schools through taxes. Given that the data for this research were gathered for only 16 school districts in South Texas, researchers are encouraged to conduct a study that will involve all school districts in the whole state and possibly the whole nation to reach more conclusive evidence on the differences between schools of choice and neighborhood schools.
\end{abstract}

\section{Keywords:}

End-of-Course Exam Passing Rates; Schools of Choice; Traditional High Schools.

\begin{abstract}
ABSTRAK
Penelitian ini dilakukan untuk mengetahui perbedaan antara sekolah pilihan dan sekolah menengah komprehensif tradisional dalam hal Ujian
\end{abstract}


Akhir Kursus (EOC) Kelas 9 State of Texas Assessments of Academic Readiness (STAAR) dalam Biologi, Bahasa Inggris 1, dan Aljabar 1 tahun ajaran 2017-2018. Analisis statistik inferensial mengungkapkan adanya perbedaan yang signifikan antara kedua jenis sekolah pada tingkat kelulusan ujian EOC mereka di ketiga bidang untuk siswa yang tidak berisiko dan untuk siswa yang tidak miskin. Sebaliknya, perbedaan yang signifikan secara statistik tidak terungkap antara kedua jenis sekolah dalam hal tingkat kelulusan ujian EOC siswa CATE dan Non-CATE mereka. Mengetahui bahwa siswa yang memiliki pilihan tampaknya berkinerja lebih baik secara akademis, pembuat kebijakan didorong untuk mempelajari kelayakan penyaluran lebih banyak dana untuk membantu distrik sekolah memperluas program pilihan sekolah mereka untuk (a) memotivasi lebih banyak siswa untuk menemukan sekolah yang sesuai dengan kebutuhan dan masa depan mereka aspirasi perguruan tinggi dan karir, dan (b) untuk meminta lebih banyak dukungan dari orang tua dan bisnis masyarakat untuk berinvestasi di komunitas mereka untuk meningkatkan sekolah melalui pajak. Mengingat bahwa data untuk penelitian ini dikumpulkan hanya untuk 16 distrik sekolah di Texas Selatan, peneliti didorong untuk melakukan penelitian yang akan melibatkan semua distrik sekolah di seluruh negara bagian dan mungkin seluruh negara untuk mencapai bukti yang lebih konklusif tentang perbedaan antara sekolah pilihan dan sekolah tetangga.

\section{Kata Kunci:}

Tingkat Kelulusan Ujian Akhir Kursus; Sekolah Pilihan; Sekolah Menengah Tradisional.

\section{Introduction}

In the United States K-12 public educational system, students attend their local neighborhood school, which offers a general comprehensive curriculum to all students regardless of their interests, preferences, or future career plans. Nevertheless, parents can still choose the school for their children by enrolling them in private schools, faith-based schools, charter schools, or by choosing their Zip code. It is common knowledge that most American families do not possess the economic luxury for private schools or residential preferences, which essentially means that they possess very limited school choices for socio-economically disadvantaged families. In essence, they have little control over the preparation for their children's future because their options are whatever the confines of their neighborhood could offer (Bischoff \& Tach, 2018).

School choice as an alternative to traditional public schooling is often debated as a promising systemic reform to the alleged failures of public education (Ellison \& Aloe, 2019). Proponents of school choice claim that when families have more control in choosing the school that matches their children's talents and interests, it will enhance learning. Those individuals who are opposed, however, argue that school choice policies could worsen class segregation, drain public schools 
funding, and may not benefit economically disadvantaged or at-risk students (Gray, 2012). Nevertheless, the percentage of students enrolled in schools of choice continues to increase (U. S. Department of Education, 2019a). The 2019 School Choice in the United States report stated that $69 \%$ of school-aged children were enrolled in assigned public schools, whereas close to $31 \%$ were enrolled in chosen public schools, private schools, or were reported as homeschooled in 2016. The increase in the number of students choosing their school suggests benefits not offered by traditional public schools. Schwalbach and Selvey (2019) proposed that, among other things, school choice is winning because it (a) is good for student safety, (b) increases parental satisfaction and involvement, (c) makes schools more accountable (d) offers options for low-income families, (e) economizes and maximizes taxpayer dollars, (f) puts competitive pressure on schools, (g) provides students with an education tailored to their needs, and leads to higher graduation rates. Additionally, school choice has the potential to reduce academic achievement gaps (Jeynes, 2014).

In a study on the achievement gaps among Black, Hispanic, and White students who attended faith-based schools, statistically, significant differences were established in reading and mathematics (Jeynes, 2010). Jeynes (2010) stressed that statistically significant differences were not present between the achievement levels of students who belong to a two-parent family and those students who belong to a single-parent family. Jeynes (2010) believed that faith-based schools, as a form of school choice, are positively affecting student learning by showing the nearly non-existent gaps between White-students, students of color, including students who were in poverty. "It is evident that schools of faith help reduce the achievement gap. Therefore the presence of school choice including faith-based school should be encouraged and supported" (Jeynes, 2010, p.170).

Meanwhile, students who were accepted into early college high schools through a lotterybased admissions process received a significantly higher number of college credits, graduated from high school, and attended college at higher rates (Edmunds et al., 2017). Early college high schools were developed within public school districts as a means to increase enrollment in postsecondary education (Edmunds et al., 2017) among students identified as at-risk and economically disadvantaged (Texas Education Agency, n.d.). Early college high schools are not traditional neighborhood schools, rather are open-enrollment schools of choice for at-risk students to earn a high school diploma, at least 60 credit hours toward a bachelor's degree or an associate degree.

Charter schools, another form of school choice, are publicly funded schools with fewer constraints but additional accountability for academic performance results (Bischoff \& Tach, 2018; Gray, 2012). In Texas, Grade 8 students enrolled in charter schools received statistically significantly higher scores in their STAAR Reading and Mathematics assessments when compared to Grade 8 students enrolled in traditional public schools (Bonner, 2017). In Ohio, public charter school policy had emerged to have had a positive impact on traditional public school achievement. Because of the recorded increases in the academic achievement of students enrolled at charter schools, failing public schools in the state were sanctioned to offer some form of public school choice (Gray, 2012). Public charter schools became an alternative choice creating a competitive 
market forcing public schools to re-evaluate their curricular programs and practices if they were to remain in the market and retain students and their families as clients (Betts, 2005).

When the demographic characteristics of urban and suburban public school neighborhoods were examined, it was noted that the presence of magnet schools such as STEM academies within neighborhood schools inside diverse communities provided an outlet for families in poverty to optout of failing traditional schools (Bischoff \& Tach, 2018). In their study of magnet schools in an urban public school district, Bischoff and Tach (2018) disclosed that this form of school choice had significantly fewer White students. The authors concluded that magnet schools such as STEM academies were attracting students from a wide variety of racial-ethnic backgrounds (Bischoff \& Tach, 2018). In contrast to the concerns of people opposed to school choice that it could worsen segregation, magnet schools, even with competitive application requirements, can enhance racial and class integration.

Bicer and Capraro (2018) compared the mathematics performance of Grade 9 students who attended an inclusive STEM academy to Grade 9 students who attended traditional public high schools or non-STEM. In this study, the students who chose to enroll in the STEM academies did not necessarily possess what would be considered an outstanding achievement in science and mathematics, but that they just had to show interest in science and mathematics and be willing to take care of their own transportation. From their investigation, Bicer and Capraro (2018) determined that students who elected to enroll in their school choice, which was a STEM academy, had statistically significantly higher mean scores compared to students who were enrolled in their neighborhood schools. Additionally, Black, Hispanic, and students in poverty who attended the STEM academies had higher mathematics test scores and also continued to achieve higher mathematics score growth when compared to the same students who were enrolled in traditional public high schools (Bicer \& Capraro, 2018). Furthermore, the authors suggested that the attributes of their school choice based on their interests provided learning experiences that extrinsically motivated the students to perform better than their peers at the traditional neighborhood schools. The learning experiences of the students increased their extrinsic motivation and could have possibly sparked their intrinsic motivation to choose a STEM career pathway. Bicer and Capraro (2018) empathized that school choices such as STEM academies should be looked at more as an influencing factor to encourage more underrepresented students to pursue STEM careers.

A new type of school choice different from charter and private schools is currently taking root in public school districts. Increases have been documented in the number of new Career and Technical Education (CTE) schools being built across the nation, which are designed as schools of choice. Students and their parents go through an application process to be accepted to the programs of study being offered in these schools. Schools compete in their recruitment efforts to market their programs to their community. The renewed interest is also present in postsecondary skills-based career pathways through career and technical certification programs with the enactment of the 2018 Strengthening Career and Technical Education for the $21^{\text {st }}$ Century Act, which increased the budget for Career, Technical, and Adult Education to $\$ 1.3$ billion. This legislation ensures that CTE will 
continue to gain momentum as a choice career pathway in secondary and postsecondary education. Responding to the rapidly changing labor market, which is increasingly dependent on STEM and skilled labor, the education department has been aggressively advocating for the expansion of school choice (Kaplan \& Owings, 2018) as a more responsive method to prepare young men and women to thrive in the future economy.

\subsection{Statement of the Problem}

Through state and federal reforms, the United States Department of Education has been aggressively advancing for the expansion of school choice (Kaplan \& Owings, 2018) as a more responsive method to prepare young men and women for the rapidly changing economic and labor market demands. The economy has evolved over the last 12 years, becoming increasingly dependent on science, technology, engineering, and mathematics disciplines and skilled labor. School districts have responded to the federal government's initiative by opening magnet schools and creating new programs consistent with parents' preferences (Arsen \& Ni, 2011), local economic needs, and labor market demands (Hughes, 2020). Currently, increases have been documented in the number of new Career and Technical Education (CTE) schools being built across the nation, which are designed as schools of choice. Students and their parents go through an application process to be accepted to the programs of study being offered in these schools. Schools compete in their recruitment efforts to market their programs to their community. Many students are choosing CTE career pathways, STEM, and engineering academies in high schools as an inexpensive but lucrative alternative to a traditional 4-year university degree that often incurs tens of thousands of student debt.

The federal government is increasing its focus on school choice over the traditional comprehensive high schools because school choice that offers a wider range of affordable hands-on, industry-driven learning grounded in skills as opposed to theory learning (U. S. Dept. of Education, $2019 \mathrm{~b}$ ) is a promising alternative to improving individual and social-economic prosperity than traditional high schools. In keeping with the government's domestic agenda on local workforce innovation, President Trump recently signed an executive order prioritizing talents and skills over college degrees in government hiring (Collins, 2020).

In 2015, the 84th Texas Legislature created the Texas Education Code chapter 12A, Districts of Innovation (TASB, 2020). Under this policy, school districts can access most of the flexibilities normally available to Texas' open-enrollment charter schools and gain exemptions from many Texas Education Code requirements such as educator certifications. Additionally, it allows for more local control to pursue specific innovations in curriculum, instruction, governance, parent or community involvement, school calendar, and budgeting.

Since the enactment of the law, 898 school districts have been designated as districts of innovation (Texas Education Agency, n.d.). Eligibility for the district of innovation designation 
under the Texas Education Code is a rating of at least acceptable performance in the applicable year's academic accountability (TEC Chapter 12A, 2016). Since their designations, most districts of innovation have built new CTE schools, learning, and training centers, which they have designated as schools of choice. Other school districts started offering industry programs of study as academies or magnet programs in existing traditional high schools or early college high schools, which are also designated as schools of choice. For families who cannot afford private schools or are too far away from charter schools, these new schools of choice within their district offer a viable alternative to the neighborhood schools that offer a general high school curriculum.

The 2019 School Choice in the United States report stated that $69 \%$ of school-aged children were enrolled in assigned public schools, whereas close to $31 \%$ were enrolled in chosen public schools, private schools, or were reported as homeschooled in 2016. Furthermore, it has been recorded that the percentage of students enrolled in schools of choice continues to increase (U. S. Department of Education, 2019a). The increase in the number of students choosing their school suggests benefits not offered by traditional public schools. Schwalbach and Selvey (2019) proposed that among other things, school choice is winning because it (a) is good for student safety, (b) it increases parental satisfaction and involvement, (c) makes schools more accountable, (d) offers options for low-income families, (e) economizes and maximizes taxpayer dollars, (f) puts competitive pressure on schools, (g) provides students with an education tailored to their needs, and (h) leads to higher graduation rates. Additionally, school choice has the potential reduce to academic achievement gaps (Jeynes, 2014).

\subsection{Purpose of the Study}

The purpose of this investigation was to determine the degree to which school choice was related to academic achievement. Specifically, schools of choice and traditional comprehensive high schools were compared in terms of their students' passing rates on the State of Texas Assessment of Academic Readiness (STAAR) End-of-Course (EOC) exams in Biology, English 1, and Algebra 1 for the following student groups: (a) Non-At Risk, (b) Non-Economically Disadvantaged, (c) Career and Technology Education (CATE) students, and (d) Non-CATE students.

\subsection{Research Questions}

The following research questions were addressed in this study: (a) What is the difference between schools of choice and traditional comprehensive schools in the Biology EOC exam passing rates of their students who were not at risk, their students who were not economically disadvantaged, of their CATE students, and of their non-CATE students?; (b) What is the difference between schools of choice and traditional comprehensive schools in the English 1 EOC exam passing rates of their students who were not at risk, their students who were not economically disadvantaged, of their CATE students, and of their non-CATE students?; and (c) What is the difference between schools of choice and traditional comprehensive schools in the Algebra 1 EOC 
exam passing rates of their students who were not at risk, their students who were not economically disadvantaged, of their CATE students, and of their non-CATE students?

\subsection{Significance of the Study}

Research regarding the effects of private and charter schools on student learning and high school graduation rates exists. For years, choices within public school districts were confined to STEM magnet programs offered by traditional high schools. To access these magnet programs, families have to choose to reside within the zoned area of the magnet high school. However, with the renewed interest in expanding school choice allowing for interdistrict and intradistrict transfers, public school districts have only recently started building more schools of choice. Because of this, investigations about the academic performance of these new schools of choice are much needed. Findings from this study have the potential to provide legislators, district, and campus leaders with important empirical data for well-informed decision-making in matters about educational policymaking and school funding.

\section{Methods}

\subsection{Research Design}

A causal-comparative research design (Johnson \& Christensen, 2012) was used. In this study, one independent variable was present: type of high school. The dependent variables were the STAAR End-of-Course exam passing rates in Biology, English 1, and Algebra 1 for Grade 9 students.

\subsection{Participants and Instrumentation}

Participants in this study were Grade 9 students who took the STAAR in Biology, English 1, and Algebra 1 EOC exams in the 2017-2018 school year from 16 school districts in South Texas. Each high school was identified as either a school of choice or a traditional comprehensive high school, otherwise known as neighborhood schools. The schools of choice were first identified from each district, after which matching traditional neighborhood schools were then determined. Using the Meets Standards as the criterion for passing the STAAR EOC exams, the passing rates for each school were determined using the schools' Texas Academic Performance Report data. Each school's Texas Academic Performance Report data contains the STAAR passing rates for each student group demographic. For this study, data for At-Risk, Non-At Risk, Economically Disadvantaged, NotEconomically Disadvantaged, CATE, and non-CATE were analyzed to determine the degree to which schools of choice differed from traditional comprehensive high schools in their students' STAAR Biology, English 1, and Algebra 1 EOC passing rates. 


\subsection{Definition of Terms}

The focus of this study was to examine the academic performances of students enrolled in campuses designated by their districts as schools of choice or traditional comprehensive high schools. Differences between schools of choice and traditional comprehensive high schools were identified using the Met Standards data from the STAAR EOC exams in Biology, English 1, and Algebra 1 as measures of academic achievement. High school students in Texas are required to pass five STAAR EOC exams to graduate. In Grade 9, they take the Biology, English 1, and Algebra 1 EOC exams. In Grade 10, they take the English 2 EOC exam, and in Grade 11, they take the U. S. History EOC exam. In these exams, students' raw and scaled scores are labeled according to three performance level descriptors, namely, (a) Did Not Meet Grade Level, (b) Approaches Grade Level, (c) Meets Grade Level, and (d) Masters Grade Level (Texas Education Agency, n.d.). For the purpose of this study, only the Meets Grade Level scores were considered. Receiving a Meets Grade Level performance is equivalent to passing the EOC exams. Meets Grade Level means that the student showed a strong understanding of the subject material and is well prepared for success in the next grade level (Texas Education Agency, n.d.).

Students who are identified as being At-Risk are students or groups of students who are under age 21 who have a potentially higher probability of failing academically or dropping out of school (Great Schools Partnership, 2013). Students who are not at risk are students or groups of students who do not have a high probability of failing academically or dropping out of school. Students who are eligible for free or reduced-price meals under the National School Lunch and Child Nutrition Program are identified as economically disadvantaged (Texas Education Agency, 2008). Students who do not qualify for free or reduced-price meals are identified as not being in poverty. For students labeled CATE, they are enrolled in a coherent sequence of a program of study in CTE that culminates in industry certification or postsecondary dual credit (Texas Education Agency, n.d.).

\section{Results and Discussions}

Prior to conducting inferential statistical procedures to address the research questions previously delineated, checks were conducted to determine the extent to which the data were normally distributed. Following these checks, parametric independent samples $t$-tests were conducted to answer all the research questions (Slate \& Rojas-LeBeouf, 2011). For the first research question, the parametric independent samples $t$-test revealed a statistically significant difference between schools of choice and traditional comprehensive schools in their Biology EOC exam passing rates for students who were not at-risk, $t(105.78)=2.70, p=.008$. This difference represented a small effect size (Cohen's $d$ ) of 0.49. The Biology EOC Exam passing rate of students in schools of choice was statistically significantly higher, 6.2 percentage points higher, than were these passing rates for students in traditional comprehensive high schools. For students who were not in poverty, the parametric independent samples $t$-test analysis did not yield a statistically significant result, $t(110.66)=2.16, p=.057$, at the conventional level of statistical significance. For students who were not economically disadvantaged, the passing rates of students on the Biology 
EOC exam were similar for students enrolled in schools of choice and their peers enrolled in traditional comprehensive high schools. Similarly, for CATE students, the parametric independent samples $t$-test analysis did not yield a statistically significant result, $t(86.32)=1.10, p=.27$. The parametric independent samples $t$-test analysis did not reveal a statistically significant difference in the Biology EOC exam passing rates between schools of choice and traditional comprehensive high schools for Non-CATE students, $t(101.20)=1.16, p=.25$. Students who were not in poverty performed similarly on this exam, regardless of the high school in which they were enrolled. Additionally, CATE and Non-CATE students in both campus types performed similarly in their Biology EOC exams. Presented in Table 1 are the descriptive statistics for this analysis.

Table 1. Descriptive Statistics for the Biology EOC Exam Passing Rates of Non-at Risk Students, Non-Economically Disadvantaged, CATE, and Non-CATE Students by High School Classification

\begin{tabular}{lccc}
\hline Student Demographic and High School Classification & $\boldsymbol{n}$ of schools & $\boldsymbol{M \%}$ & $\boldsymbol{S D \%}$ \\
\hline Non-At Risk Students & & & \\
$\quad$ Schools of Choice & 61 & 89.51 & 10.437 \\
$\quad$ Traditional Schools & 59 & 83.31 & 14.347 \\
Non-Economically Disadvantaged & 60 & 69.03 & 26.175 \\
$\quad$ Schools of Choice & 59 & 59.98 & 25.137 \\
$\quad$ Traditional Schools & & & \\
CATE & 43 & 52.72 & 30.396 \\
$\quad$ Schools of Choice & 51 & 46.02 & 27.923 \\
$\quad$ Traditional Schools & & & \\
Non-CATE & 51 & 59.84 & 24.92 \\
$\quad$ Schools of Choice & 58 & 54.57 & 22.31 \\
$\quad$ Traditional Schools & & &
\end{tabular}

Concerning the second research question, the parametric independent samples $t$-test yielded a statistically significant difference between schools of choice and traditional comprehensive schools in their English 1 EOC exam passing rates for students who were not at-risk, $t(105.78)=2.70, p$ $<.001$. This difference represented a moderate effect size (Cohen's $d$ ) of 0.67. For students who were not at-risk and who were enrolled in schools of choice, their English 1 EOC Exam passing rate was statistically significantly higher, 10.06 percentage points higher, than were these passing rates for students in traditional comprehensive high schools. For the English I EOC exam passing rates of students who were not in poverty, the parametric independent samples $t$-test yielded a statistically significant difference between schools of choice and traditional comprehensive schools, $t(114.56)=$ 2.47, $p=.015$. This difference represented a small effect size (Cohen's $d$ ) of 0.45. Students who were not poor and who were enrolled in schools of choice had a statistically significantly higher average passing rate in their English 1 EOC Exam, 12.08 percentage points higher, than the passing rates on this exam for their peers who were enrolled in traditional comprehensive high schools. 
Concerning the English 1 EOC exam passing rates of CATE students, the parametric independent samples $t$-test did not reveal a statistically significant difference between schools of choice and traditional comprehensive schools, $t(88.10)=1.36 p=.18$. Students who were CATE students performed similarly on this exam, regardless of the high school in which they were enrolled. Similarly, the parametric independent samples $t$-test analysis did not yield a statistically significant difference at the conventional level of statistical significance in the English 1 EOC exam passing rates between schools of choice and traditional comprehensive high schools for Non-CATE students, $t(91.52)=1.90, p=.06$. Non-CATE students achieved similar performance rates on this exam regardless of the type of high school in which they enrolled. Readers are referred to Table 2 for the descriptive statistics for this analysis.

Table 2. Descriptive Statistics for the English 1 EOC Exam Passing Rates of Non-At Risk Students, Non-Economically Disadvantaged, CATE, and Non-CATE Students by High School Classification

\begin{tabular}{lccc}
\hline Student Demographic and High School Classification & $\boldsymbol{n}$ of schools & $\boldsymbol{M \%}$ & $\boldsymbol{S D \%}$ \\
\hline Non-At Risk Students & & & \\
$\quad$ Schools of Choice & 61 & 84.82 & 13.09 \\
$\quad$ Traditional Schools & 59 & 74.76 & 16.55 \\
Non-Economically Disadvantaged & & & \\
$\quad$ Schools of Choice & 60 & 60.13 & 26.18 \\
$\quad$ Traditional Schools & 59 & 48.05 & 25.14 \\
CATE & 46 & 37.59 & 27.27 \\
$\quad$ Schools of Choice & 58 & 30.74 & 23.05 \\
$\quad$ Traditional Schools & & & \\
Non-CATE & 49 & 52.92 & 27.78 \\
$\quad$ Schools of Choice & 58 & 43.53 & 22.26 \\
$\quad$ Traditional Schools & & &
\end{tabular}

For the third research question, the parametric independent samples $t$-test revealed the presence of a statistically significant difference between schools of choice and traditional comprehensive schools in their Algebra 1 EOC exam passing rates for students who were not atrisk, $t(113.48)=2.63, p=.01$. This difference represented a small effect size (Cohen's $d$ ) of 0.48 . For students who were at risk and who were enrolled in schools of choice, their Algebra 1 EOC Exam passing rates were statistically significantly higher, 8.06 percentage points higher, than were the passing rates of their peers enrolled in traditional comprehensive high schools. For students who were not economically disadvantaged, the parametric independent samples $t$-test yielded a statistically significant difference between schools of choice and traditional comprehensive schools, $t(110.66)=2.16, p=.033$, in their Algebra I EOC exam passing rates. This difference represented a small effect size (Cohen's $d$ ) of 0.40. Students who were not in poverty and who were enrolled in schools of choice had a statistically significantly higher average passing rate in their Algebra 1 EOC Exam, 9.66 percentage points higher, than the passing rates on this exam for their peers who were enrolled in traditional comprehensive high schools. 
Concerning the Algebra1 EOC exam passing rates of CATE students, the parametric independent samples $t$-test did not yield a statistically significant difference between schools of choice and traditional comprehensive high schools for, $t(79.23)=1.85, p=.069$. Students who were CATE students performed similarly on this exam, regardless of the high school type in which they were enrolled. The parametric independent samples $t$-test yielded a statistically significant difference between schools of choice and traditional comprehensive schools in their Algebra 1 EOC exam passing rates for Non-CATE students, $t(84.93)=2.19, p=.031$. This difference represented a small effect size (Cohen's $d$ ) of 0.43. The Algebra 1 EOC Exam passing rates of non-CATE students were statistically significantly higher, 8.82 percentage points higher than the students in the traditional comprehensive high schools. Presented in Table 3 are the descriptive statistics for this analysis.

Table 3. Descriptive Statistics for the Algebra 1 EOC Exam Passing Rates of Non-At Risk Students, Non-Economically Disadvantaged, CATE, and Non-CATE Students by High School Classification

\begin{tabular}{lccc}
\hline Student Demographic and High School Classification & $\boldsymbol{n}$ of schools & $\boldsymbol{M \%}$ & $\boldsymbol{S D \%}$ \\
\hline Non-At Risk Students & & & \\
$\quad$ Schools of Choice & 61 & 76.57 & 15.33 \\
$\quad$ Traditional Schools & 59 & 68.51 & 18.14 \\
Non-Economically Disadvantaged & & & \\
$\quad$ Schools of Choice & 59 & 54.51 & 26.80 \\
$\quad$ Traditional Schools & 59 & 44.85 & 21.44 \\
CATE & & & \\
$\quad$ Schools of Choice & 42 & 43.52 & 27.77 \\
$\quad$ Traditional Schools & 52 & 33.67 & 22.92 \\
Non-CATE & & & \\
$\quad$ Schools of Choice & 50 & 51.18 & 23.99 \\
$\quad$ Traditional Schools & 58 & 42.36 & 16.49 \\
\hline
\end{tabular}

In this investigation, the extent to which differences were present in student academic performance as a function of their high school classification was examined for Grade 9 students who took the 2018 STAAR EOC exams. For students who were not at-risk, the academic performances of the students enrolled in schools of choice in the Biology, English 1, and Algebra 1 EOC exams were statistically significantly higher than the students enrolled in traditional neighborhood schools. This result held true for students who were not economically disadvantaged for English 1 and Algebra 1. However, the mean difference between the Biology EOC exam passing rates between schools of choice and neighborhood schools approached, at .057, but did not reach the conventional level of statistical significance. Students from schools of choice outperformed their peers from the traditional neighborhood schools by a little over nine percentage points.

In contrast, CATE students who attended schools of choice did not outperform their peers who attended traditional neighborhood schools in all three STAAR EOC exams. However, their 
passing rates were at least six percentage points higher. However, CATE students enrolled in schools of choice almost significantly performed higher in Algebra 1 compared to the students enrolled in traditional high schools. The mean difference of 9.85 percentage points produced a $p$ value of .069. Similarly, Non-CATE students who were enrolled in schools of choice had higher passing rates in Algebra 1, but not in Biology or English 1. It should be noted, however, that the mean difference of 9.38 percentage points in the English 1 passing rates between schools of choice and traditional neighborhood schools almost yielded significant results, with a $p$-value of .060. NonCATE students in schools of choice almost statistically significantly performed better than their peers in traditional high schools.

\subsection{Implications for Policy and Practice}

The results discussed above several present implications for policy and practice. Knowing that students who have choice appear to perform better academically, policymakers are encouraged to study the feasibility of channeling more funding to help school districts expand their school choice programs to (a) motivate more students to find the school that fit their needs and their future college and career aspirations, and (b) to solicit more support from parents and community businesses to invest in their communities to improve schools through taxes. District and campus leaders are encouraged to evaluate their current curriculum offerings based on local community assessment needs and student career pathways to respond more effectively in expanding their school choice programs. Parents, together with their children, are also encouraged to explore the program offerings of all the high schools in their assigned and neighboring school districts to make informed decisions about choosing the best school that will best prepare their sons and daughters for their future.

\subsection{Recommendations for Future Research}

Based on the results of this study, the following recommendations for future research can be made. As the data in this research included only students who were not at risk, and who were not economically disadvantaged, researchers are encouraged to expand this investigation to include students identified as at-risk, economically disadvantaged, including English Language Learners and special populations, as well as to other measures of academic performance such as Advanced Placement and dual credit programs. Given that the data for this research were gathered for only 16 school districts in South Texas, researchers are encouraged to conduct a study that will involve all school districts in the whole state and possibly the whole nation to reach more conclusive evidence on the differences between schools of choice and neighborhood schools. Lastly, researchers are encouraged to investigate non-cognitive factors that may contribute to the higher academic achievement of students enrolled in schools of choice to inform the leaders of traditional high schools in evaluating their support system for their students. 


\section{Conclusion}

In conclusion, the high school classification addressed herein was related positively to the academic performance of Grade 9 students as measured by their STAAR EOC exam passing rates. Students enrolled in schools of choice received higher passing rates in all three content areas when compared to their peers enrolled in traditional neighborhood high schools. For the most part, NonCATE students who were not at risk, and who were not in poverty, and who attended schools of choice had statistically significantly higher passing rates on their EOC exams in Algebra 1, English 1 , and Biology than their peers who were enrolled in traditional high schools. Because of these results, differences exist in students' academic performance between schools of choice and traditional comprehensive high schools. However, to state that schools of choice are a better alternative than neighborhood schools in terms of their Grade 9 academic performance is inconclusive because data on only a limited number of student groups were analyzed herein. As such, readers are urged to be cautious in any generalizations they might make from the results of this investigation.

\section{References}

Arsen, D. D., \& Ni, Y. (2011). The charter movement. The School Administrator, 68(7). https://www.aasa.org/SchoolAdministratorIssue.aspx?id=19572.

Betts, J. R. (2005). The economic theory of school choice. In J. R. Betts \& T. Loveless (Eds.), Getting choice right (pp. 14-39). Washington, DC: Brookings Institution Press.

Bicer, A., \& Capraro, R. M. (2018). Mathematics achievement in the secondary high school context of STEM and non- STEM schools. School Science \& Mathematics, 119(2), 61-71. doi:10.1111/ssm.12321.

Bischoff, K., \& Tach, L. (2018). The racial composition of neighborhoods and local schools: The role of diversity, inequality, and school choice. City \& Community, 17(3), 675-701. doi:10.1111/cico.12323.

Bonner, W. H. (2017). A comparison of academic performance and financial disparity at Texas charter schools and traditional public schools. Dallas Baptist University.

Cohen, J. (1988). Statistical power analysis for the behavioral sciences (2nd ed.). Hillsdale, NJ: Lawrence Erlbaum.

Collins, M. (2020, June 27). Trump signs an order prioritizing job skills over college degrees in government hiring. USA Today, Retrieved from https://www.usatoday.com/.

DeAngelis, C. A., \& Erickson, H. H. (2018). What leads to successful school choice programs? A review of the theories and evidence. CATO Journal, 38(1), 247-265.

Edmunds, J. A., Unlu, F., Glennie, E., Bernstein, L., Fesler, L., Furey, J., \& Arshavsky, N. (2017). Smoothing the transition to postsecondary education: The impact of the early college model. Journal of Research on Educational Effectiveness, 10(2), 297-325. doi:10.1080/19345747.2016.1191574. 
Ellison, S., \& Aloe, A. M. (2019). Strategic thinkers and positioned choices: Parental decision making in urban school choice. Educational Policy, 33(7), 1135-1170.

Gray, N. L. (2012). School choice and achievement: The Ohio charter school experience. CATO Journal, 32(3), 557-579.

Great Schools Partnership. (2013). The glossary of education reform. Retrieved from https://www.edglossary.org/glossary/a/.

Hughes, K. (2020). Perkins V: Putting student futures first. Retrieved from https://ies.ed.gov/ncee/edlabs/regions/southwest/blogs/perkins5-cte.aspx.

Jennings, J. L. (2010). School choice or schools' choice? Managing in an era of accountability. Sociology of Education, 83(3), 227-247.

Jeynes, W. H. (2010). Religiosity, religious schools, and their relationship with the achievement gap: A research synthesis and meta-analysis. The Journal of Negro Education, 263-279.

Jeynes, W. H. (2014). School choice and the achievement gap. Education \& Urban Society, 46(2), 163-180.

Johnson, B. \& Christensen, L. (2012). Educational Research, Qualitative, Quantitative and Mixed Approach. (4th ed). California: SAGE Publication.

Kaplan, L. S., \& Owings, W. A. (2018). Betsy DeVos's education reform agenda: What principals and their publics need to know. NASSP Bulletin, 102(1), 58-84.

Onwuegbuzie, A. J., \& Daniel, L. G. (2002). Uses and misuses of the correlation coefficient. Research in the Schools, 9(1), 73-90.

Nichols, M. (2017). Can I choose to have grit? Non-cognitive skills, behavior, and school choice. Journal of School Choice, 11(4), 622-641. https://doi:10.1080/15582159.2017.1395636.

Schwalbach, J. \& Selvey, J. (2019). Here are 10 reasons school choice is winning. The Heritage Foundation. The Heritage Foundation. https://www.heritage.org/education/commentary/here-are-10-reasons-school-choicewinning.

Slate, J. R., \& Rojas-LeBouef, A. (2011). Calculating basic statistical procedures in SPSS: A selfhelp and practical guide to preparing theses, dissertations, and manuscripts. Ypsilanti, MI: NCPEA Press.

Texas Association of School Boards. (2020). Districts of innovation frequently asked questions [PDF file]. https://www.tasb.org/services/legal-services/tasb-school-lawesource/governance/districts-of-innovation/documents/districts_of_innovation.pdf.

Texas Education Agency. (n.d.). Understanding the STAAR report card [PDF File]. https://www.texasassessment.com/uploads/ets-understandingreportcard-transcript4.pdf.

Texas Education Agency. (n.d.). High school testing program guide [PDF File]. https://tea.texas.gov/sites/default/files/end-of-course.pdf.

U. S. Department of Education. (2009). School choices for parents. https://www2.ed.gov/parents/schools/choice/definitions.html. 
U. S. Department of Education. (2019a). Bridging the skills gap: Career and technical education in high school. https://www2.ed.gov/datastory/cte/index.html\#data-story-title.

U. S. Department of Education, (2019b). Split secondary and postsecondary awards in 2019 [PDF file]. https://cte.ed.gov/grants/state-allocations.

Wang, K., Rathburn, A., Musu, L., National Center for Education Statistics (ED), \& American Institutes for Research (AIR). (2019). School Choice in the United States: 2019. NCES 2019-106. In National Center for Education Statistics. National Center for Education Statistics. (Report)

Woodcock, J. B., \& Olson Beal, H. K. (2013). Voices of early college high school graduates in Texas: A narrative study. The High School Journal, 97(1), 56. doi:10.1353/hsj.2013.0021. 